\title{
The Impact of International Financial Reporting Standards Adoption on Global Acceptability of Financial Statements of Firms in Nigeria
}

\author{
OLAOYE, AYOOLA AZEEZ \\ Bsc (Ed), (Acct), Msc (Acct) \& ACA
}

Doctoral Student, School of Post Graduate Studies, Faculty of Management Sciences, Department of Accounting, Ekiti State University, Ado-Ekiti, Nigeria

\begin{abstract}
Nowadays business has become global activities. Nigeria is not left out of making international transactions. Before the introduction of the global standards called International Financial Reporting Standards (IFRS), different countries have developed their own national accounting standards or adopted that of other countries as a basis for financial reporting. Any information generated for economic decisions from financial statements prepared under different countries' local accounting standards often not comparable. There exists a gap in literature on the studies of global acceptability of the financial statements of Nigerian firms after adopting IFRS in Nigeria.This study therefore, examines the impact of IFRS adoption on global acceptability of financial statements of firms in Nigeria after migration. A purposive sampling technique was adopted to draw a sample size of 96 from the study population of all the accountants and accounting lecturers in Osun State, Nigeria. Both primary and secondary data were used to elicit responses from the questionnaire administered. Multiple regression and Pearson correlation statistical tools were used to analysis the data generated for the study. The results from data analysis show the correlation of $0.850,0.845, \mathrm{R}$ value of $0880, \mathrm{R}$-square of 0.774 and the $\mathrm{p}$ value of 0.00 . The correlation results show that IFRS adoption has a strong positive relationship with global acceptability of financial statements. Since the p-value is less than 0.01 level of significant $(0.00<0.01)$, then null hypotheses should be rejected. Therefore, there is significant impact of IFRS adoption on global acceptability of financial statements of firms in Nigeria. This study concludes that by transmitting to IFRS, business organizations in Nigeria will enjoy full benefits of credible financial statements. This will ease their access to global capital markets thereby increasing their access to external capital and this will also attract foreign investors into this country which will serve as a basis for economic growth. This study therefore, recommends that the professional accounting bodies in Nigeria should make IFRS training a part of Mandatory Continuous Professional Education at reduced costs and the accounting lecturers should see the implementation of IFRS adoption as part of their professional and national responsibilities by embracing the teaching of students based on IFRS benchmarks in order to build human capacity that will support the production of global acceptable financial reports for businesses in Nigeria.
\end{abstract}

Keywords: International Financial Reporting Standards, Financial Statements, Firms Global acceptability.

DOI: $10.7176 /$ RJFA/11-9-07

Publication date:May $31^{\text {st }} 2020$

\section{Introduction}

The globalization of the world's economy and markets lead companies and nations to become world global business players. In addition, more investments take place on a global level. Nigeria is not left out from making international transactions. In a free enterprise economy the business organization, otherwise known as the firm, is an important decision-making unit (Osunwole, 2013). A business is a social and lawful human activity, the primary aim of which is to make profit. We can rightfully say that a business is the organized effort of persons utilizing resources within an organizational context to produce and distribute goods and services for the purpose of profit making. There are various forms of business organizations such as sole proprietorship, partnership and limited liability companies. The business entities are required to keep track records of their activities taking place from time to time (Nigerian Accounting Standards Board (NASB), 2010). The Company and Allied Matter Act (CAMA, 1990) as amended stipulated that all the registered limited liability companies under it coverage are to publish their audited annual accounts and reports in the at least two national news papers yearly in compliance with the Statement of Accounting Standards (SAS) issued by the Nigeria Accounting Standards Board (NASB) now called the Financial Reporting Council of Nigeria (FRCN) prior to International Financial Reporting Standards (IFRSs) adoption (Osunwole, 2013). Financial Statement is the accounting reports in respect of the economic activities of an enterprise prepared periodically and usually at the end of every financial year. These statements form an integral part of the company's annual accounts and reports of business entities (Olaoye, 2012). 
Business organizations rely heavily on accounting professional bodies and other educational institutions to provide future accounting experts to man the financial resources of their entities and there is need for capacity building to bridge the IFRS knowledge gaps but various research results have revealed that there this capacity building is not enough for handling the new transformation in accounting architecture, while many of Nigerian tertiary institutions are yet to review and update their accounting curricula, and even yet to alter their teaching methods to account for the foreseen transition to IFRS and to adequately prepare accounting students for the new challenges (Izedonmi,2001).

The review of prior literature also indicates that the adoption of IFRS will enhance global relevance, acceptability and credibility of Nigerian firms' financial statement. In a study conducted by Nwakaeze (2010) on the regulation of financial reporting for accountability in quoted companies in Nigeria sought to correlate the non-compliance with the financial standards and governance code in twenty (20) selected quoted companies on the Nigeria Stock Exchange (SEC) in Delta State, Nigeria reveals that there is a general problem of accurate financial reporting of annual accounts and reports of some business organizations due to non- compliance with the IFRS requirements. Without IFRS-based financial statements, barriers to cross border listing cannot be eliminated and Nigerian companies cannot stand a better chance of raising capital abroad because only the few companies precisely banks are listed in the foreign stock exchange (Jacob \& Madu, 2008). Also, a review of literature indicated that there is a mising gap on the studies of global acceptability of financial statements of Nigerian firms prepared based on IFRS framework.

These situations call for this study to be carried out to examining the impact of IFRS adoption on global uniformity and credibility of financial statements of the business entities in Nigeria. It is believed that findings from this study will gear up the government, policy makers, business operators, the preparers and other users of financial statements of business entities to appreciate the need that fast track the adoption of IFRS in Nigeria which will enable firms in Nigeria to have access to cross-border fund raising and enjoy global acceptability of their financial statements. It is against this background that this study seeks to examine the impact of IFRS adoption on global acceptability of financial statement of firms in Nigeria. Specifically, this study confirms whether the training institutions (Tertiary institutions and accounting professional bodies) have updated their accounting curricula to reflect the IFRS benchmarks in teaching of accounting students; whether all the business organizations have implemented Findings from this study will expose the readers and researchers to understand the IFRS frameworks as a basis of their financial reporting in Nigeria and the conceptual differences between Nigerian Generally Accepted Accounting Practices (GAAP) called SAS and the IFRS.

\section{Conceptual Review}

Since 1960s, business has become global activities and Nigerian businesses are making more and more international transactions. Cross border listing is now a common place and the accounting firms are beginning to follow their growing corporate clients into other countries in order to maintain services (Okundi, 2013). Thus, for business organizations in Nigeria to account and attract finance from multilateral organizations and other foreign investors, it makes sense to have global financial reporting benchmarks that are understood and acceptable by these organizations. The global convergence of accounting standards is attracting much attention in the academic and professional accounting literature (Epstein, 2009). The adoption of international accounting standards has become a trend across the countries given the enormous benefits it provide countries and multinational companies (Barth, 2007).

In satisfying the global requirement, the International Accounting Standard Committee (IASC) established in 1973 was reformed and renamed as International Accounting Standards Board (IASB) in London in 2001. The Board was saddled with responsibilities among others to introduce a new set of standards titled "International Financial Reporting Standards (IFRS). The Board consists of 14 members from around the world. IASB (2007) claims that the term IFRS consists of IFRS issued by IASB; International Accounting Standard (IAS) issued by International Accounting Standard Committee (IASC); interpretations issued by the standard interpretations Committee (SIC) and the International Financial Reporting Interpretation Committee. Both IFRS and IAS are equally enforceable because there is no difference between the two. Having a single set of financial reporting standards will increase market liquidity, decrease transaction costs for investors, lower cost of capital and facilitate international capital formation and flows (Epstein, 2009). Jacob et al (2009) describes IFRS as a single set of high quality and globally accepted accounting standards that can enhance comparability of financial reporting across the world. Olaoye (2012) defines IFRS as a single set of globally accepted high quality accounting standard which prescribe how particular types of transactions and other events should be reported in financial statements.

Before the introduction of International Financial Reporting Standards (IFRS), different countries developed their own national accounting standards or adopted that of other countries. Fosbre, Kraft \& Fosbre (2009) affirm that the movement of business toward a global economy has accelerated the need to move toward global accounting standards. When financial statements are prepared under different countries' accounting 
standards, they are often not comparable. If one company gives financial reports under Ghanaian accounting standards (GNAS) and another under United States' accounting standards (U. S. GAAP), an investor will not be able to put the two together without making a number of adjustments to accounting entries of the two companies. Without adjustments, the comparison becomes difficult and meaningless (Anao, 2012). There is the need to attract capital from investors, creditors and financial institutions both locally and externally for expansion of businesses and also to set up the new ones. This birthed the need of a global set of accounting standards called IFRS. The move to adopt IFRS in Nigeria began in year 2010 (Ezeani, 2012).

Previous literature review confirms that IFRS have been adopted by many countries and international organizations as a basis for financial reporting. Russia adopted IFRS in 2004. The European Union adopted IFRS in 2005 and many other countries have either adopted IFRS or are in the process of adopting them either outright or piecemeal (Obazee, 2009). In 2007, Hong Kong adopted national standards that are identical to IFRS standards and China listed 150 companies on the Hong Kong Exchange (Cai \& Wong, 2010). Australia and New Zealand adopted national standards described as IFRS equivalents and Switzerland permits the use of IFRS or US GAAP in financial reporting (Alistair, 2010). Ecuador adopted IFRS in 2008. Chile adopted IFRS in 2009. Brazil adopted IFRS in 2010. Canada, India, Japan and Korea also adopted IFRS in 2011 (Cai et al, 2010). In Africa, many countries such as Algeria, benin, Botwana, Gambia, Ghana, Kenya, Malawi, Namibia, N-Sudan, Rwanda, Sierra Leone, South Africa, Nigeria, Tanzania, Uganda, Zimbabwe some other also have adopted IFRS (Okundi, 2013).

In Nigeria as well, this was witnessed on 28 July 2010 when the Nigerian Federal Executive Council (FEC) approved January 2012 as the effective date for the convergence of Nigerian accounting standards (SAS or NGA AP) to International Financial Reporting Standards (IFRS). The then Nigerian President, Good-luck Ebele Jonathan repealed the Nigerian Accounting Standard Board Act No 22, 2003 and enacted the Financial Reporting Council of Nigeria (FRCN) Act 2011. The FRCN is a unified independent regulatory body for Accounting, Auditing, Actuarial, Valuation and Corporate Governance. This legislation is meant not only to create the enabling environment for the implementation of IFRS adoption in order to guarantee the acceptable financial reporting regime in both public and private sectors of Nigeria economy, and to ensue wealth creation and economic transformation nation (Aganga, 2011). Goodlock Jonathan therefore charged the Chief Executive Officer of the FRCN, Obazee, to liaise with the Nigeria Accounting Associations and bodies, and tertiary institutions regulatory bodies with a view to reviewing the accounting curricula that will reflect the studies of IFRS in the syllabus of higher institutions and accounting professional bodies (Aganga, 2011).

The adoption was structured in such a way that all the stakeholders will be using the IFRS by January, 2014. The public interest entities quoted on the Nigeria Stock Exchange with a minimum of N500m in shareholders' funds are required to commence implementation by January, 2012. Other Public Interest entities quoted on the Nigerian Stock Exchange but with Share holders' funds below N500m are required to commence implementation by January 2013. Then the Small and Medium Scale Enterprises (SMEs) are required to commence implementation by January 2014. Subsequent to this announcement by the now defunct NASB; several events and activities have been embarked upon by both public sector entities as well as private sector organizations to ensure that the transition is seamlessly achieved. This includes local and international conferences and workshops for the purpose of information dissemination and knowledge transfer (Aganga, 2011).

Several researches have confirmed that adoptions of IFRS at country level have increased direct foreign investment (Ajibade, 2011). Barth (2007) while arguing for adoption of IFRS, specifies that a single set of internationally accepted standards is expected to lower the cost of processing financial information and auditing to users of capital market, increase uniformity and comparability of financial statements across companies in different countries thereby easing the job of investment analysts, facilitate easy access to foreign investments as well as liberalization of capital markets. Similarly, Cai et al (2010) also supports the adoption of IFRS arguing that adoption of IFRS at the firm level has enhanced accounting quality and financial performance Cai et al (2010) make further argument that the adoption of IFRS is a means of lowering the cost of capital, a better means of allocating capital as well as providing greater market liquidity. Cai et al (2010) go further to argue that convergence to IFRS is likely to enhance financial reporting by so doing, multinational companies will have a cost advantage and hence there will be no need for companies to report using more than one set of accounting standards.

Based on the reviewed related studies, the adoption and implementation of IFRS in Nigeria will enhance credible financial reporting in Nigeria. Credibility of financial statements means that the financial report issued in Nigeria can be compared with those issued in any other country that has adopted IFRS. With IFRS application for financial reporting in Nigeria, compilation of meaningful information on the performance of various reporting entities will be guaranteed. With IFRS adoption, financial statements prepared in Nigeria will be reliable, understandable and comparable with others countries. These will forester investment decisions and ensure a more optimal allocation of resources across the world economy. Therefore, all the business entities that 
are yet to converge are advised to do so in less than no time for them to enjoy the benefits attached to IFRS adoption in the globe. But as observed here in Nigeria, the request for the adoption of IFRS comes with some dif ficulties and challenges like inadequate training facilities and resource persons, inconsistencies in applicable laws, cost versus benefit analysis and lack of readiness of some training institutions to embrace the IFRS adoption and implementation in Nigeria.

\subsection{Conceptual Gaps between IFRS and Nigerian GAAP (SAS)}

The major difference between SAS and IFRS is in the extensive use of fair value under the latter which give rise to differences in recognized income and carrying values of assets and liabilities. For better understanding of these gaps between the two accounting standards, table 1 below is used to highlight the significant differences that necessitated the adoption and implementation of IFRS in Nigeria (NASB, 2007 \& IASB, 2007).

Table 1: Major Differences between IFRS and Nigerian GAP (SAS)

\begin{tabular}{|c|c|c|}
\hline SUBJECTS/ITEMS & IFRS & NIGERIAN GAAP (SAS) \\
\hline $\begin{array}{l}\text { Components of Financial } \\
\text { Statements }\end{array}$ & $\begin{array}{l}\text { Comprises of: } \\
\text {-Statements of Financial Position: } \\
\text {-Statement of Comprehensive } \\
\text { Income (e.g revaluation gains, } \\
\text { foreign exchange etc), } \\
\text {-Statement of Cash flow and } \\
\text {-Statement of changes in equity and } \\
\text { notes to the accounts. (IAS 1) }\end{array}$ & $\begin{array}{l}\text { Comprises of: } \\
\text {-Balance sheet } \\
\text { - Profit and loss } \\
\text { - Cash flows statement } \\
\text { - Notes to Accounts } \\
\text { - Value Added Statement } \\
\text { - Cash flow statement for public } \\
\text { companies only (CAMA 2004) }\end{array}$ \\
\hline Borrowing costs & $\begin{array}{l}\text { Full disclosure of borrowing costs } \\
(\boldsymbol{I} A \boldsymbol{S} 23)\end{array}$ & $\begin{array}{llll}\text { SAS has no substantive standard on } \\
\text { borrowing costs }\end{array}$ \\
\hline Statement of Cash Flows & $\begin{array}{l}\text { Statement of Cash Flows Mandatory } \\
\text { for all entities }\end{array}$ & $\begin{array}{l}\text { Not applicable for Non-listed } \\
\text { Companies }\end{array}$ \\
\hline $\begin{array}{l}\text { Depreciation of } \\
\text { Property, Plant, and } \\
\text { Equipment }\end{array}$ & $\begin{array}{l}\text { Each significant part of PPE is } \\
\text { depreciated, component parts treated } \\
\text { as separate items if they have different } \\
\text { useful lives or providing economic } \\
\text { benefits in a different pattern. }\end{array}$ & Wholesome depreciation of PPE \\
\hline Classification of Assets & $\begin{array}{l}\text {-Non- current assets/PPE } \\
\text {-Current Assets- Inventory, Trade } \\
\text { receivable accounts }\end{array}$ & $\begin{array}{l}\text {-Fixed assets } \\
\text {-Current Assets- Stock and Debtors }\end{array}$ \\
\hline Classification of Liability & $\begin{array}{l}\text {-Non-current Liability } \\
\text {-Current Liability- Trade payable } \\
\text { accounts }\end{array}$ & $\begin{array}{l}\text {-Long-term Liability } \\
\text {-Current Liability- Creditors }\end{array}$ \\
\hline PPE- measurement & $\begin{array}{l}\text { Uses Fair Value as a measurement } \\
\text { base. Fair value is the amount for } \\
\text { which an asset could be exchanged, or } \\
\text { a liability settled, between } \\
\text { knowledgeable, willing parties in an } \\
\text { arm's length transaction (IFRS 13) }\end{array}$ & Uses cost as a measurement base \\
\hline $\begin{array}{l}\text { Format for Balance sheet } \\
\text { and Profit and Loss } \\
\text { Accounts }\end{array}$ & $\begin{array}{l}\text { One format for balance sheet } \\
\text { One format for profit and loss }\end{array}$ & $\begin{array}{l}2 \text { formats for balance sheet } \\
4 \text { formats for Profit and Loss (CAMA 2004, } \\
\text { Schedule } 2 \text {. }\end{array}$ \\
\hline
\end{tabular}

Source: IFRS Resources (2009) \& NASB (2010)

\subsection{Theoretical Review}

This study was anchored on the theory of "Pure impression management model" (PIMM) of accounting propounded by Keppler in 1995. The theory stated that observance of unified accounting standards would serves as a linkage construct by continually reminding people of the need to act in accordance with the prevailing form and content of financial reporting. In the real sense, financial reporting cannot be accepted by general public or investors if certain guidelines/standards that are generally expected are not followed and observed. This theory recognizes that uniformity and observance of relevant standards are meant for the smooth functioning of the public companies (Ezeani, 2012). The theory of PIMM is relevant to this study in that it focuses on behavioural aspect of accounting and the need to comply with the observance of world generally acceptable unified accounting standards and practices for acceptability of financial reports of entities world-wide. The PIMM recognizes that a large measure of trust and self accountability is necessary for the smooth functioning of 
institutions. Therefore, if PIMM of accountability is properly utilized by the management of companies or institutions in Nigeria, it will fetch a good result.

\subsection{Empirical Review}

Anao (2012) in his study on adoption of IFRS at firm level and on FRC Act, Nigeria Roadmap to IFRS and implication of accounting education in Nigeria, found that firms adopting IFRS had exhibited higher accounting quality in the post-adoption period than they did in the pre-adoption period. The outcome of the study also disclosed that if financial reports are prepared by firms under the global financial reporting benchmarks, will make decisions about the flow of economic capital to be easy for Nigerian companies to stand a better chance of raising capital abroad. The study concluded that few companies precisely banks are listed in the foreign stock exchange. In, a study on observance of standards and codes in Nigeria conducted by IMF/World Bank (2004) revealed significant differences in the size of the Nigerian local standards (SAS) and IFRS and the complexity of IFRS.

In another study carried out by Cai and Wong (2010) on the Effects of IFRS adoption on global capital market integration. Findings from the study showed that having a single set of internationally acceptable financial reporting standards will eliminate the need for restatement of financial statements and this would consequently facilitate international movement of capital and greater integration of the global financial markets. The study concluded that IFRS based financial statements will certainly attract foreign investors into the country thereby increasing firms' access to external capital. The study also concluded that anybody with the knowledge of IFRS application in Nigeria can obtain job in any part of the world which will alleviate poverty. Also, the result of a study conducted by Ezeani (2012) on the Adoption of international financial reporting standards (IFRS) to enhance financial reporting in Nigeria Universities confirmed that majority of accounting quality indicators improved after IFRS adoption.

\section{Research Methodology}

The data for this study were collected through the administration of structured questionnaires. Population of the study is made up of professional and non professional accountants and accounting lecturers in the employment of some selected firms and tertiary institutions in Nigeria. The sample size however, consists of 420 persons selected at random. All the questionnaires of 240 copies distributed to respondents were returned valid and analyzed. The instrument consisted of a 13 - term survey questionnaire with a Likert scale response options, of Strongly Agree (SA - 5); Agree (A - 4); Strongly Disagree (SD- 3); Disagree (D - 2); Undecided (U - 1). The validation of the questionnaires was done through the use of expert in the field of Accountancy and a Cronbach's Alpha reliability test that yielded a stability Co-efficient of $79.2 \%$ which was considered well enough for the study. The work experience, job status and educational attainments of the respondents were considered when the questionnaires were being administered on the respondents. The opinions of respondents were sought by using percentage to analyze the responses of questions 1, 2, 3, 4 and 5 from the questionnaire administered and Pearson correlation and multiple regression analysis statistical tools to test the hypotheses at $5 \%$ level of significance using SPSS version 20.

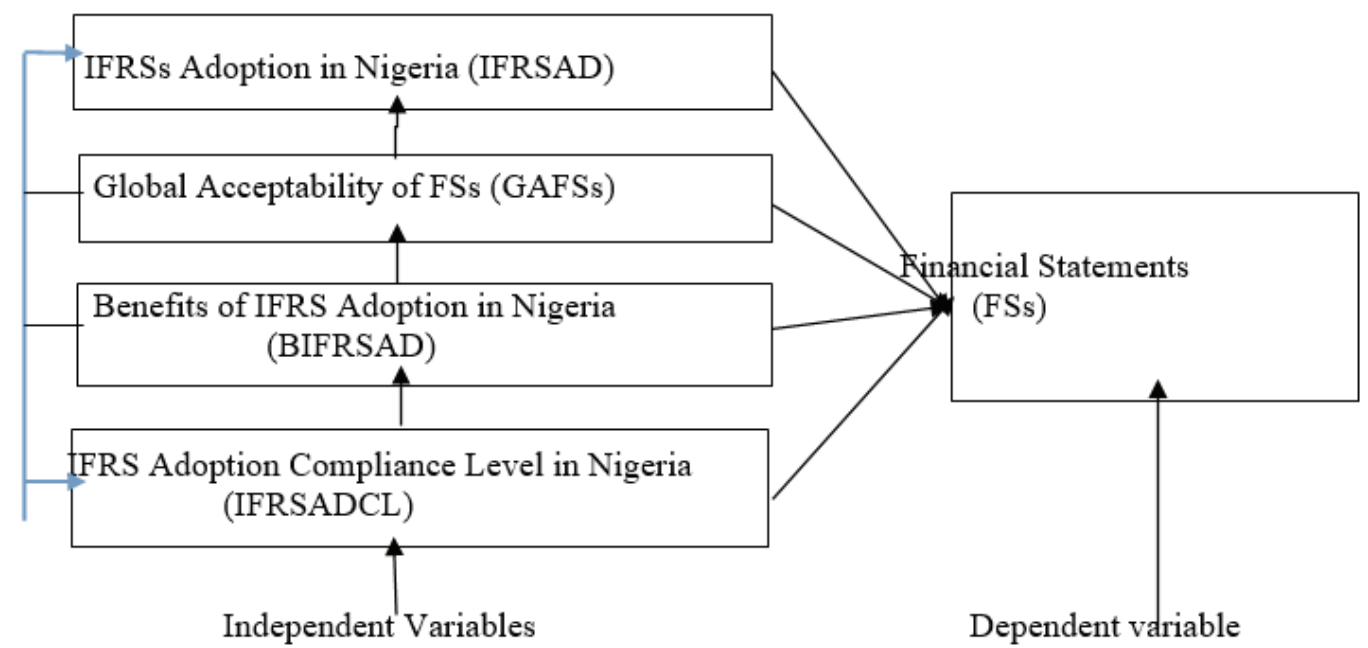

Figure 1.1: Conceptual Model of Adopting IFRS in Nigeria

Source: Author's Compilation (2020)

The table 1.1 above shows the conceptual model was developed to show the impact of the independent variable (IFRSAD) on the dependent variable (CFSs). The independent of IFRS adoption is made up of three predictable variables of GAFS, BIFRSAD and IFRSADCL Thus, the model gives the snapshot of the essence, 
elements and benefits of IFRS adoption and it impact on the Nigerian firms' financial statements.

\subsection{Model Specification and Identification of Variables}

This study employed regression model of forensic accounting services and fraudulence practices adopted by Anuolam et al (2016) as follow:

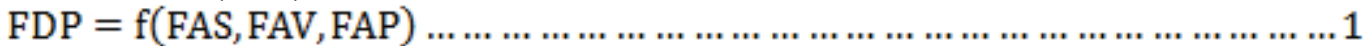

$$
\begin{aligned}
& \mathrm{FDP}=\mathrm{f}\left(\alpha_{0}+\beta_{1} \text { FAS }+\beta_{2}\right. \text { FAV } \\
& +\beta_{3} \text { FAP) } \\
& \text { where: } \alpha_{0} \text { is constant and } \beta_{1}, \beta_{2}, \beta_{3}>0
\end{aligned}
$$

The dependent variable of fraudulent practices (FDP) was used as a function of the three components of independent variables of FAS (Forensic Accounting Services), FAV (Forensic Accounting Validation) and FAP (Forensic Accounting Practices). This study therefore replaced the variables used by Anuolam et al (2016) with a dependable variable of financial statements (FSs) as a function of three predictable variables of GAFS, BIFRSAD and IFRSADCL to form the specific objectives and research hypotheses in order to capture the impact of IFRS adoption on global acceptability of financial statements in Nigeria. The model is as follow:

$$
F S s=f\left(\beta_{0}+\beta_{1} G A F s+\beta_{2} \text { BIFRSAD }+\beta_{3} I F R S A D C L+U t\right) \ldots \ldots \ldots \ldots \ldots 2
$$

where: $\beta_{0}$ is constants, $U_{\mathrm{t}}$ stochastic error term and $\beta_{1}, \beta_{2}, \beta_{3}$ are parameters /coefficients.

3.2 A Priori Expectation: $\beta_{1}, \beta_{2}, \beta_{3},>0$

\section{Data Presentation and Discussion of Results}

Table 4.1 Reliability Statistics

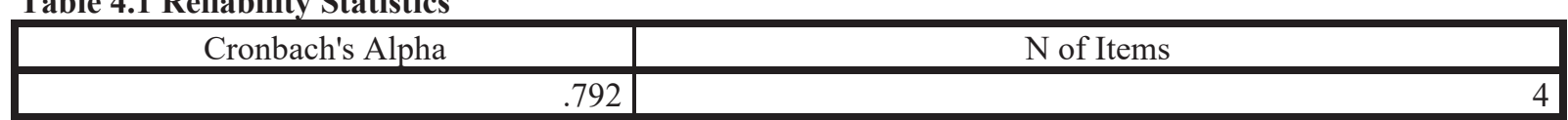

Source: Author's Computation (2020)

Table 4.1 above showed Cronbach's Alpha coefficient of 0.792 which above the value of Cronbach's Alpha

\begin{tabular}{|c|c|c|c|c|c|}
\hline & & $\begin{array}{c}\text { Global } \\
\text { Acceptability } \\
\text { of FSs }\end{array}$ & $\begin{array}{c}\text { Benefits of } \\
\text { IFRS } \\
\text { Adoption }\end{array}$ & $\begin{array}{c}\text { IFRS } \\
\text { Adoption } \\
\text { Compliance } \\
\text { Level }\end{array}$ & $\begin{array}{l}\text { IFRS Based } \\
\text { FSs }\end{array}$ \\
\hline \multirow{3}{*}{$\begin{array}{l}\text { Global Acceptability of } \\
\text { FSs }\end{array}$} & Pearson Correlation & 1 & $.964^{* *}$ & $.371^{* *}$ & $.850^{* *}$ \\
\hline & Sig. (2-tailed) & & .000 & .000 & .000 \\
\hline & $\mathrm{N}$ & 96 & 96 & 96 & 96 \\
\hline \multirow{3}{*}{$\begin{array}{l}\text { Benefits of IFRS } \\
\text { Adoption }\end{array}$} & Pearson Correlation & $.964^{* *}$ & 1 & $.345^{* *}$ & $.848^{* *}$ \\
\hline & Sig. (2-tailed) & .000 & & .001 & .000 \\
\hline & $\mathrm{N}$ & 96 & 96 & 96 & 96 \\
\hline \multirow{4}{*}{$\begin{array}{l}\text { IFRS Adoption } \\
\text { Compliance Level }\end{array}$} & Pearson Correlation & $.371^{* *}$ & $.345^{* *}$ & 1 & $.495^{* *}$ \\
\hline & Sig. (2-tailed) & .000 & .001 & & .000 \\
\hline & & 96 & 96 & 96 & 96 \\
\hline & Pearson Correlation & $.850^{* *}$ & $.848^{* *}$ & $.495^{* *}$ & 1 \\
\hline \multirow[t]{2}{*}{ IFRS Based FSs } & Sig. (2-tailed) & .000 & .000 & .000 & \\
\hline & $\mathrm{N}$ & 96 & 96 & 96 & 96 \\
\hline
\end{tabular}
coefficient recommended by George and Mallery (2003) that the statistical reliability value is expected be 0.70 or above. This indicates that the questionnaire is reliable.

Table 4.2 Correlations Analysis

**. Correlation is significant at the 0.01 level (2-tailed).

Source: Author's Computation (2020)

The above correlation results in table 4.2 above shows a strong relationship between IFRS adoption in and IFRS based financial statement given the correlation result of 0.850 between the explanatory independent variable of global acceptability of financial statements and IFRS based financial statement and the correlation of 0.845 between the benefit of IFRS adoption and IFRS based financial statements. Then the p-value of 0.000 is less than significant level i.e. $(0.00<0.01)$, therefore hull hypothesis should be rejected. In both cases, hull hypotheses are rejected. That is, IFRS adoption in Nigeria has significant impact on global acceptability of financial statements of firms in Nigeria. But the correlation result of 0.495 indicate a weak relationship between the explanatory variable of compliance level with IFRS adoption and the IFRS based financial statements. 
Therefore null hypothesis is accepted indicating that many business organizations and tertiary institutions in Nigeria did not comply with the implement IFRS adoption in Nigeria.

Table 4.3 Regression Model Summary

Analysis of research hypotheses on the impact of IFRS adoption on global acceptability of financial statements of firms in Nigeria.

\begin{tabular}{|l|r|r|r|r|}
\hline Model & R & \multicolumn{1}{|c|}{ R Square } & Adjusted R Square & Std. Error of the Estimate \\
\hline 1 & $.880^{\mathrm{a}}$ & .774 & .767 & .44788 \\
\hline
\end{tabular}

a. Predictors: (Constant), IFRS Adoption Compliance Level, Benefits of IFRS Adoption, Global Acceptability of FSs

Source: Author's Computation (2020)

Table 4.3 above indicates that the coefficient of relationship (R) (0.880) for the hypotheses at a significant level of 0.01 shows a strong relationship. Then the coefficient of determination $\left(\mathrm{R}^{2}\right)(0.774)$ shows a moderate positive correlation of the studies variables, which indicates that about $77.4 \%$ of variation in the dependent variable (FSs) is explained by the independent variables (IFRSAD) or the ability of the regression line to predict dependent variable (FCs) is about $77.4 \%$. The other $22.6 \%$ is explained by other factors outside the model and the error term. Thus, null hypothesis is rejected and alternative hypotheses accepted. That is, International Financial Reporting Standards (IFRS) adoption in Nigeria has significant impact on global acceptability of financial statements of firms in Nigeria.

\subsection{Summary of Results}

a. The adoption of IFRS will enhance global acceptability of financial statements of firms in Nigeria.

b. Many business organizations and tertiary institutions are yet fully complied with the implementation of adoption of IFRS in Nigeria.

c. The adoption of IFRS in Nigeria will ease consolidation of financial information of parent companies in Nigeria with their subsidiaries abroad.

d. Adoption of IFRS will enable Nigerians to enjoy all benefits attached to it.

\section{Conclusion and Recommendations}

This paper provides the empirical evidence to assess global acceptability of IFSR- based financial statements of business organizations in Nigeria. Based on the findings, it was concluded that the adoption of IFRS is a right step in the right direction. The results of this study correlates with result of a study conducted by Osunwole (2013) on the appraisal of the role of IFRS in ensuring full disclosure of relevant information by business organization in Nigeria, where the result therein showed that the adoption of IFRS will play significant roles in the area of financial information disclosure and relevance during the presentation of locally prepared financial reports of business organizations for cross boarder purposes.

Adoption of IFRS for financial reporting in Nigeria means that the information produced is final. Consolidation of financial information of parent companies in Nigeria and their subsidiaries outside Nigeria is made easy. This is because the same standards are applied. The same applies if a parent company has subsidiaries in Nigeria. The reviewed literature also revealed that the adoption of IFRS as a basis for financial reporting in Nigeria wills certainly promote Nigeria companies' access to global capital markets thereby increasing the companies' access to external capital and attract foreign investors into this country. This study therefore, recommends that the professional accounting bodies in Nigeria should make IFRS training a part of Mandatory Continuous Professional Education at reduced costs and the accounting lecturers should see the implementation of IFRS adoption as part of their professional and national responsibilities by embracing the teaching of students based on IFRS benchmarks in order to build human capacity that will support the production of global acceptable financial reports for businesses in Nigeria.

\section{REFERENCES}

Aganga, O. (2011). Work shop on Attracting Investment into Nigeria Held at Trascorp, HiltonHotel, Abuja July 20th 201.1

Anuolam, O. M, Onyema, T. E. \& Ekeke, U. (2016). Forensic accounting and financial crimes: Adopting the inference, relevance and logic solution approach. West African Journal of Industry and Academic Research, $17,126-132$.

Ajibade, M. (2011). Financial Reporting Council (Formerly National Accounting Standard Board (NASB). In Essien-Akpan (Ed). International Financial Reporting Standards (IFRS). The Role of the Chartered Secretary and Administrator. A paper presented at the $35^{\text {th }}$ Conference of Institute of Chartered Secretaries and Administrators of Nigeria (ICSAN), Lagos Sheraton Hotels and Towers, October 26th and 27th.

Anao, A. R. (2012), FRC Act and Nigeria Roadmap to IFRS: Implication of Accounting Education in Nigeria. A 
Paper presented at a Workshop/Training organized by the Financial Reporting Council of Nigeria for University Lecturers in Enugu, Enugu State, Nigeria.

Barth, M. (2007). Global financial reporting: Implications for US academics. The Accounting Review, 83, 11591179 .

Cai, F., \& Wong, H. (2010). The Effects of IFRS adoption on global capital market integration. International Business \& Economic Research Journal, 9(10), 25-34.

Esptein, B. J (2009). The Economic Effect of IFRS Adoption, CPA Journal March, 26-31.

Ezeani, N. S. (2012). Adoption of international financial reporting standards (IFRS) to enhance financial reporting in Nigeria Universities. Arabian Journal of Business and Management Review (OMAN Chapter), 2(3).

Fosbre, A. B., Kraft \& Fosbre (2009). The Globalization of Accounting Standards: IFRS versus US GAAP. Global Journal of Business Research, 3(1), 61-71.

International Accounting Standards Board (IASB) (2007). Available from www.lasb.org. (Accesed date $16 / 4 / 2012)$.

IFRS Resources (2009). American Institute of Certified Public Accountants, http:/www. ifrs.com/ ifrs-faqs.html.

IMF/World Bank (2004). Report on the Observance of Standards and Codes (ROSC) Nigeria Accounting and Audit; http://www.worldbank.org/ifa/rosc aa.html.

Izedonmi, P. F. (2001). An evaluation of the level of banks' compliance with accounting standards issued by the Nigerian Accounting Standards Board (NASB). The Nigerian Banker Journal. 12, 9-34.

Jacob, R. A., \& Madu, C. N (2009). "International Financial Reporting Standards: An indicator of high quality." International Journal of Quality \& Reliability Management, 26, 712-737.

Nigerian Accounting Standards Board(NASB) (2010). Adoption of International Financial Reporting Standards Report of the Committee on Road Map to the Adoption of IFRS.

Nwakaeze, E. (2010). Olamide, F. (2010). Audit quality, corporate Governance and firm characteristics in Nigeria. International Journal of Business Management December, 5 (5), 10-15

Obazee, J. O. (2009). Enforcement of accounting standards in Nigeria and efforts at aligning with International Standards, A paper presented at NASB for Lectures of Accounting and related subject on SASs, IFRSs and IPSASs Seminar, Benin City April 2930 Mary et al. 010

Osunwole, O.O (2013). Appraisal of the role of International Financial Reporting Standards (IFR) in ensuring full disclosure of relevant information by business organizations in Nigeria. A paper presented at the $2^{\text {nd }}$ annual national conference of Falculty of Financial Studies, Osun State Polytechnic, Iree, between $23^{\text {rd }}-27^{\text {th }}$ September, 2013, pg 1-17

Olaoye A.A (2012). Advanced Financial Accounting, Nigeria, Adex Publishing Limited

Okundi, B. (2013). Tax implications of implementing IFRSs. Price Water house Coopers (n.d.). A option of IPSAS in Ghana: Prospects, Challenges and the Way Forward. Retrieved from www.acoa13.com 